\title{
Spectrofluorimetric Determination of Nateglinide in Pharmaceutical Preparations
}

\author{
N. Orcun Ozcelik (Corresponding author) \\ Istanbul University, Faculty of Pharmacy, Department of Analytical Chemistry, \\ 34116, Beyazit, Istanbul, Turkey \\ E-mail: n.orcunozcelik@gmail.com \\ Sevgi Tatar Ulu \\ Istanbul University, Faculty of Pharmacy, Department of Analytical Chemistry, \\ 34116, Beyazit, Istanbul, Turkey \\ Serap Saglik Aslan \\ Istanbul University, Faculty of Pharmacy, Department of Analytical Chemistry, \\ 34116, Beyazit, Istanbul, Turkey
}

\begin{abstract}
In this study, Selective assay methods have been presented for the analysis of nateglinide in tablets. The assay involves derivatization with 5-(dimethylamino) naphthalene-1-sulfonyl chloride (dansyl chloride) which is a specific reagent in the analysis of primary and secondary amines. Optimum conditions of the reaction between nateglinide and dansyl chloride were investigated and it was found that the reaction proceeds quantitatively at $\mathrm{pH} 11.0,40{ }^{\circ} \mathrm{C}$ in $10 \mathrm{~min}$ when the mole ratio of reagent to the drug was 16 . After the completion reaction, the derivative was extracted with dichloromethane from the reaction medium and the fluorescence intensity was measured at $517 \mathrm{~nm}$ with excitation at $397 \mathrm{~nm}$.

The developed method was successfully applied to the assay of nateglinids in tablets and the results were compared statistically with those obtained by pharmacopeia method (USP XXXIV). There is no significant difference between the two methods in the respect of mean values and the standard deviations at $95 \%$ confidence level.
\end{abstract}

Keywords: Nateglinide, 5-(dimethylamino) naphthalane-1-sulfonyl chloride (Dansyl Chloride), Derivatization, Determination, Spectrofluorimetric method.

DOI: $10.7176 / \mathrm{JSTR} / 5-8-06$

\section{INTRODUCTION}

Nateglinide (Figure 1) is an amino acid (phenylalanine) derivative that is chemically and pharmacologically different from other antidiabetics. Early phase insulin secretion, reducing the rise of blood sugar and Hbaic after meals.

Early stage insulin secretion is a fundamental mechanism for maintaining normal glycemia control.

The methods developed for the analysis of the drug active ingredients containing the primary and secondary amine group are usually made by Derivatization. For this purpose, dansyl chloride (Figure.2) was used as a derivation agent in this thesis.(Abd El-Ghaffar et al. 2011, Aksamija et al. 2012, Wang et al. 2007, Romero et al 2006, Higashi, and Fujii 2004)

It was thought to develop a simple sensitive and reliable method of analysis for nateglinide by differentiating it with dancil chloride, validate the methods developed and apply it as a combination to the analysis of this drug in pharmaceutical preparations. A spectrofluorimetric method was developed in this direction.

\section{MATERIALS AND METHODS}

\section{Chemicals}

Nateglinide was supplied from Deva Pharmaceuticals (Istanbul, Turkey). Dansyl chloride was purchased from Sigma Aldrich (Missouri, USA). Starlix tablets (120 mg Nateglinide), was purchased from Novartis Pharmaceuticals Corporation (Basel, Switzerland). Methanol, Sodium bicarbonate, Sodium hydroxide, Trifluoroacetic Acid, Acetonitrile, Dehydrated sodium sulphate were purchased from Merck KGaA 
(Germany). Dichloromethane, Acetone were purchased from Sigma Aldrich (Missouri, USA). All the chemicals and ultra pure water which used in the assays were HPLC grade.

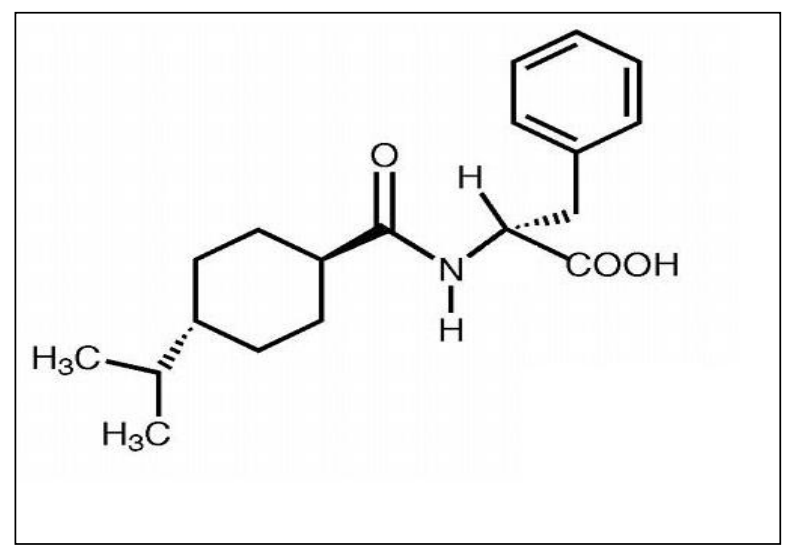

Figure 1- Chemical structure of the Nateglinide

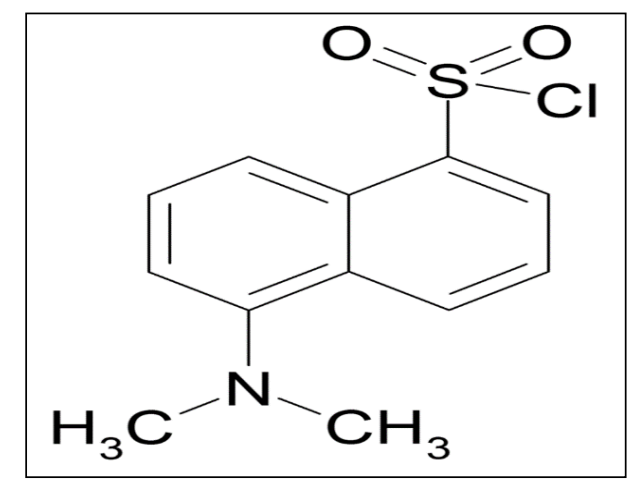

Figure 2- Chemical structure of the Dansyl Chloride

\section{Apparatus and Other Materials}

A Spectrofluorometer (Shimadzu RF-1501) HPLC system was employed for analysis. Shimadzu UV-160A A Spectrophotometer and Quartz tubes $1 \mathrm{~cm}$ (QS 1000) (10x10x45 mm) was used for absorbance measurement. While performing the comparison HPLC method CBM 10A system control unit, LC 10 at SPD-10 a UV-visible absorbance detector, DGU (with 2A helium gas extraction unit) was used. Chromatographic data was acquired using Shimadzu LC-Solution software. A C18 analytical column (HYPERSIL BDS 4,6 x $150 \mathrm{~mm} 5 \mu \mathrm{m}$ particle size) was used for separation. The mobile phase consisting of Acetonitrile and $0.05 \%$ solution of trifluoroacetic acid (23:27). The flow rate of the mobile phase was 1.5 $\mathrm{mL} / \mathrm{min}$ with detection at $210 \mathrm{~nm}$. The column temperature was $25^{\circ} \mathrm{C}$ and sample temperature was $25^{\circ} \mathrm{C}$. The injection volume was $10 \mu \mathrm{l}$. Diluent was Acetonitrile and water (11:9). Denver fragrance TB 2150 was used as a balance. For pH measurements wtw ph 526 model, was used. Electro-mag brand Vortex Mixer, Bransonic 221 brand ultrasonic bath, Memmert WB 10 brand water bath with thermostat, Janetzki T 5 brand centrifuge, Eppendorf $100 \mu \mathrm{l}$ and $1000 \mu \mathrm{l}$ brand automatic pipettes, Casio FX-3600P brand calculator, $1 \mathrm{~cm}$ glass tubs (OS 1000) (10x10x45 mm), ultra pure water device (Younglin instrument), reaction tubes (12mL with screw, cover), Bubbles $(5,10,25,50$ and $100 \mathrm{~mL})$ grade and transfer pipettes, filter paper (blue tape) used during analysis.

\section{Method Development Studies: Determination of Optimum Reaction Conditions for Derivatization}

Literature studies have shown that the reaction between dansyl chloride and the substances containing the primer and secondary amine group is carried out at alkaline $\mathrm{pH}$, in the hot or room temperature, and the resulting derivative is measured by fluorescence intensity after being extracted with an organic solvent. In the light of the information in the literature, the following experiments were conducted to determine the best 
conditions for the reaction between nateglinide and dansyl chloride (Higashi et al. 2008, Wang et al. 2007, Romero et al 2006, Higashi, and Fujii 2004). According to these literature investigations. Some experimental studies have been carried out.

\section{Extraction Solvent}

$100 \mu \mathrm{L}$ of the nateglinide stock solution at a concentration of $10 \mu \mathrm{g} / \mathrm{mL}$ was taken up into the reaction tubes, and $100 \mu \mathrm{L}$ of pH 11.0 sodium bicarbonate buffer and $100 \mu \mathrm{L}$ of dansyl chloride were added, followed by heating in a water bath at $40^{\circ} \mathrm{C}$ for 10 minutes. The resulting derivative was extracted in 5 different organic solvents, such as methanol, acetone, acetonitrile, dichloromethane and chloroform ( $3 \times 2 \mathrm{~mL})$. The anhydrous $\mathrm{Na}_{2} \mathrm{SO}_{4}$ was added to the organic phases combined in a $10 \mathrm{~mL}$ flask and then the organic solvent was extracted to volume. Spectra were taken with the aid of a spectrofluorimeter against the blank experiment prepared in the same conditions.

\section{pH Effect}

$100 \mu \mathrm{L}$ of the nateglinide solution at a concentration of $10 \mu \mathrm{g} / \mathrm{mL}$ was taken into the reaction tube. Then, $100 \mu \mathrm{L}$ of sodium bicarbonate buffer (8.5-12.0) at various pHs was added and $100 \mu \mathrm{L}$ of dansyl chloride was added. Heated for 10 minutes in a water bath at $40{ }^{\circ} \mathrm{C}$. The cooled solution was extracted with $3 \times 2$ $\mathrm{mL}$ dichloromethane. Extracts was taken into the $10 \mathrm{~mL}$ volumetric flask. The organic phases combined in the flask were combined with anhydrous $\mathrm{Na}_{2} \mathrm{SO}_{4}$ and then the volume was diluted with dichloromethane. Spectra were taken with the help of a spectrofluorimeter against the blank experiment prepared under the same conditions.

\section{Temperature and Reaction Time}

$100 \mu \mathrm{L}$ of the nateglinide solution at the concentration of $10 \mu \mathrm{g} / \mathrm{mL}$ was taken up in the reaction tubes and pH 11.0 sodium bicarbonate buffer was added. Then $100 \mu \mathrm{L}$ of dansyl chloride was added. The tubes were kept at room temperature, $40,50,60^{\circ} \mathrm{C}$ for $10,20,30,40,50,60$ minutes.

\section{Effect of Dansil Chloride amount on the nateglinide-dansyl Derivative}

$100 \mu \mathrm{L}$ of the nateglinide solution at a concentration of $10 \mu \mathrm{g} / \mathrm{mL}$ was taken up in the reaction tubes and $100 \mu \mathrm{L}$ of the solution was added from a $\mathrm{pH} 11.0$ sodium bicarbonate buffer. Then $25,50,100,150,200$, $250,300,400,450,500,550 \mu \mathrm{L}$ of the dansyl chloride solution $(0.2 \mathrm{mg} / \mathrm{mL})$ added to the solution.

\section{Analytical method validation}

According to the results obtained from the method development study, optimum method conditions were determined and the method was validated according to these conditions.

\section{Preparation of solutions \\ Nateglinide Solution}

Stock solution: nateglinide $100 \mathrm{mg}$ was transfered to $100 \mathrm{~mL}$ of bubble solution and completed in volume with methanol $(1 \mathrm{mg} / \mathrm{mL}) .10 \mathrm{~mL}$ of this solution was transferred to $100 \mathrm{~mL}$ balloon joje and completed with water volume $(100 \mu \mathrm{g} / \mathrm{mL})$. In the study, a solution containing nateglinide was used in $10 \mu \mathrm{g} / \mathrm{mL}$ concentration diluted with water.

\section{Dansyl Chloride Solution}

In the determination of reaction conditions, a solution prepared in acetone was used for the concentration of $0.2 \mathrm{mg} / \mathrm{mL}$ of densil chloride.

\section{Buffer Solutions}

$50 \mathrm{~mL} 0.1 \mathrm{~m}$ sodium bicarbonate solution by adding $0,1 \mathrm{M} \mathrm{NaOH}$ required amounts of $\mathrm{pH}$ 's $8,5,9,0,9,5$, $10,0,10,5,11,0,12,0$ the buffer solutions have been prepared.

\section{Precision and Accuracy}

For precision and Recovery evaluation at three different concentrations (25, 100 and $250 \mathrm{ng} / \mathrm{mL})$, six of the nateglinide-containing solutions were prepared. In line with this aim Intraday and Interday analysis were done.

\section{Linearity and range}

To prove the linear response relation, fluorescence intensity of the standard solutions between $25.0-250$

$\mathbf{5 7}$ | P a g e 
ng. $\mathrm{mL}^{-1}$ at 5 different concentrations $\left(25,50,100,150\right.$ and $\left.250 \mathrm{ng} \cdot \mathrm{mL}^{-1}\right)$ were measured and linearity curves were plotted. After solutions were analyzed, $y=a x+b$ threshold was found and regression analysis was performed (y: area, a: slope, b: intercept, $x$ : concentration, $\mathrm{mg} / \mathrm{mL}$ ).

\section{Specificity}

Specificity test was performed to demonstrate the ability of the analytical method to measure only the intended substances in a given sample. Excipients such as Lactose monohydrate, Croscarmellose sodium, Microcrystalline cellulose, Povidone, Hydroxypropyl methyl cellulose, Colloidal silicon dioxide, Magnesium stearate, Talc, Polyethylene glycol 4000, Yellow iron oxide (E 172), Titanium dioxide (E 171) in tablets containing $120 \mathrm{mg}$ nateglinide The solutions in the concentrations of $100 \mu \mathrm{g} . \mathrm{mL}-1$ were prepared and studied as in sample preparation.

\section{Robustness}

With the Robustness parameter the effect of changes in the method parameters and solution stability were examined. For this aim parameters which Changes in the Method Parameters and Solution Stability were performed.

\section{Changes in the Method Parameters}

- $\quad$ Excitation Wave Length

- $\quad$ Emission Wave Length

- $\quad$ Reaction Time

- $\quad$ Dansyl Chloride Amount

$$
\begin{aligned}
& : \lambda_{\text {eks }}=398 \text { and } \lambda_{\text {eks }}=396 \\
& : \lambda_{\text {ems }}=518 \text { and } \lambda_{\text {ems }}=516 \\
& : 10 \mathrm{~min} . \pm 1 \mathrm{~min} . \\
& : 400 \pm 5 \mu \mathrm{l}
\end{aligned}
$$

\section{Solution Stability}

The effect of the nateglinide-dansyl derivative on the fluorescence intensity values of the solution was examined at room temperature in daylight, in the dark and in the dark at $+4{ }^{\circ} \mathrm{C}$ for a period of time to examine the stability of the nateglinide-dansyl derivative in dichloromethane solution.

\section{Results and Discussion}

The spectrofluorometric method developed for the quantitative determination of nateglinide tablets is based on the reaction between dansyl chloride and this substance containing the secondary amine group. (Figure 2)

Dansil forms derivatives with strong fluorescence observed in the yellow reaction in the derivative reaction with chlorine primer and secondary amine. Progress in the aqueous medium of the reaction is of considerable advantage in that the overexpression of the reagent does not detriment to the assay and proceeds with minimal amounts of the amine.

In literature searches, it has been shown that Dansyl chloride (Figure 3) reacts with amines at alkaline $\mathrm{pH}$ and hot, and the resulting product is extracted from the reaction medium with an organic solvent. Optimum conditions were investigated for this information light. Optimization studies showed that the best results were obtained in $\mathrm{pH} 11.0$ sodium bicarbonate buffer. In order to determine the optimum reaction temperature and reaction time, various temperatures and various reaction times were studied. The optimum reaction temperature, which is also in the direction of these studies, was determined to be 10 minutes at 40 ${ }^{\circ} \mathrm{C}$.

In Method Development Studies Optimum reaction conditions carried out such, Extraction Solvent effect on fluorescence intensity (Table 1, Figure 4, Figure 5 and Figure 6), pH Effect (Table 2 and Figure 7) Temperature and Reaction Time (Table 3 and Figure 8) Effect of Dansil Chloride amount on the nateglinidedansyl Derivative (Table 4 and Figure 9). According to the results obtained from these studies optimum method conditions were determined.

The maximum excitation and emission wavelengths for this solvent were determined to be $397 \mathrm{~nm}$ and 517 $\mathrm{nm}$, respectively, when the various fluorescence intensities were obtained when the various organic solvents were used for the extraction of the nateglinide-dansyl derivative from the reaction medium after completion of the derivatization reaction and consequently dichloromethane was used.

It was observed that the auxiliary substances prepared did not react with Dansil chloride and did not affect the fluorescence intensity in Specificity analysis.

The linearity between the concentration and the fluorescence intensity after the specified optimum conditions is $25-250 \mathrm{ng} / \mathrm{mL}$ Correlation coefficient between concentration and areas of more than 0.999 was sought. (Table 5, Table 6, Figure 10). The calculated correct equation is $\mathrm{F}=3.0135 \mathrm{C}+119.37$. The LOD and LOQ values were 6.17 and $18.68 \mathrm{ng} / \mathrm{mL}-1$, respectively. (Table 7) 
Table 1. Maximum excitation ( $\lambda$ exs) and emission $(\lambda \mathrm{em})$ wave length and fluorescence intensity values of the nateglinide-dansyl derivative in various organic solvents

\begin{tabular}{lcc}
\hline & $\underline{\lambda_{\text {exs }} / \lambda_{\mathrm{em}}(\mathbf{n m})}$ & Fluorescence Intensity \\
\hline Methanol & $401 / 532$ & 193 \\
Acetone & $419 / 527$ & 315 \\
Acetonitrile & $419 / 531$ & 385 \\
Dichloromethane & $397 / 517$ & 1007 \\
Chloroform & $404 / 502$ & 953 \\
\hline
\end{tabular}

Table 2. Effect of $\mathrm{pH}$ on the nateglinide-dansyl Derivative

\begin{tabular}{cccccccc}
\hline $\mathbf{p H}$ & $\mathbf{8 , 5}$ & $\mathbf{9 , 0}$ & $\mathbf{9 , 5}$ & $\mathbf{1 0 , 0}$ & $\mathbf{1 0 , 5}$ & $\mathbf{1 1 , 0}$ & $\mathbf{1 2 , 0}$ \\
\cline { 2 - 7 } Fluorescence Intensity & 90 & 188 & 182 & 280 & 317 & 482 & 354 \\
\hline
\end{tabular}

Table 3. Effect of Time and Temperature on the nateglinide-dansyl Derivative

\begin{tabular}{|c|c|c|c|c|c|c|}
\hline Time & 10 & 20 & 30 & 40 & 50 & 60 \\
\hline Tempereture ( & & & & & & \\
\hline Room Temperature & 444 & 478 & 446 & 354 & 448 & 444 \\
\hline 40 & 480 & 412 & 410 & 416 & 428 & 346 \\
\hline 50 & 282 & 280 & 252 & 232 & 262 & 220 \\
\hline 60 & 122 & 108 & 57 & 66 & 101 & 79 \\
\hline
\end{tabular}<smiles>CC(C)[C@H]1CC[C@H](C(=O)N[C@@H](Cc2ccccc2)C(=O)O)CC1</smiles>

Nateglinide<smiles>CN(C)c1cccc2c(S(=O)(=O)Cl)cccc12</smiles>

Dansyl Chloride<smiles>CC(C)[C@H]1CC[C@H](C(=O)N([C@H](Cc2ccccc2)C(=O)O)S(=O)(=O)c2cccc3c(N(C)C)cccc23)CC1</smiles>

Nateglinide Dansyl Chloride Derivative

Figure 3. The derivatization reaction mechanisim between Nateglinide and Dansyl Chloride 


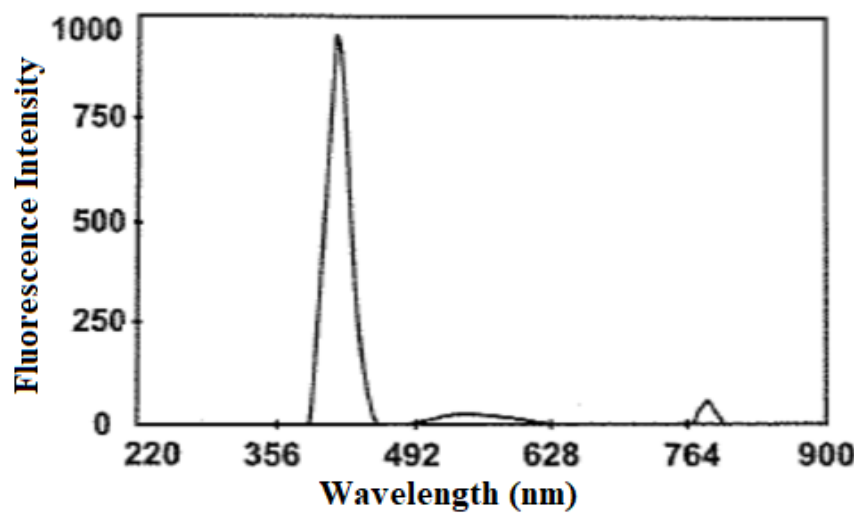

Figure 4. Emmision Spectrum of Blank

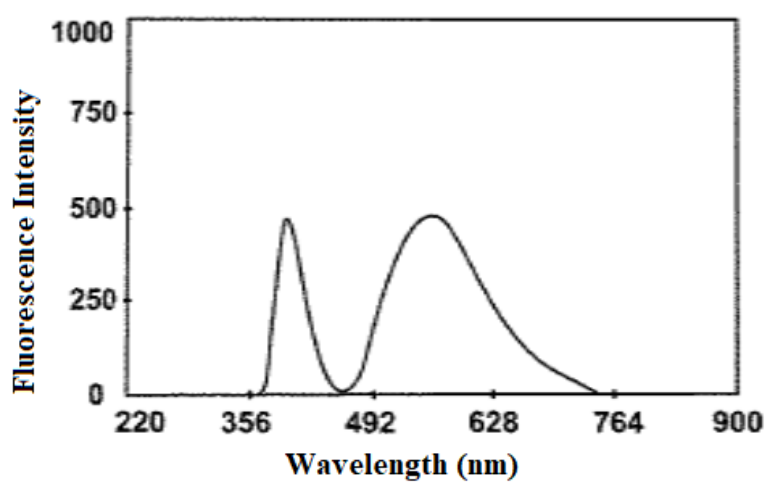

Figure 5. Emmision Spectrum of $100 \mathrm{ng} / \mathrm{mL}$ Nateglinide Dansil Chloride Derivative $\left(\lambda_{\mathrm{em}}=517 \mathrm{~nm}\right)$

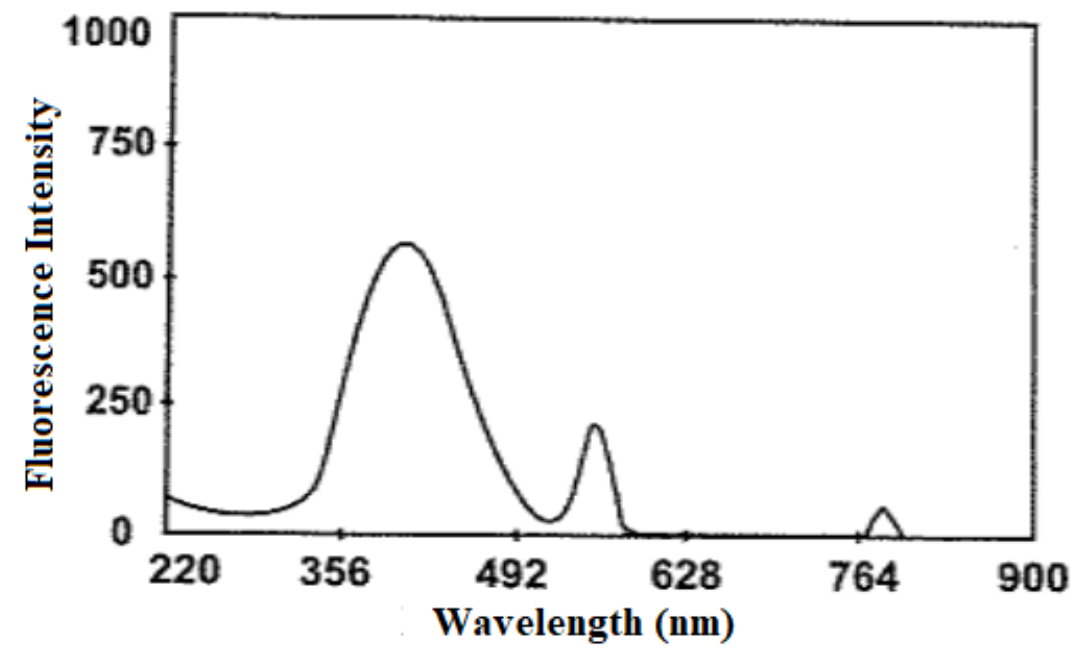

Figure 6. Excitation Spectrum of $100 \mathrm{ng} / \mathrm{mL}$ Nateglinide Dansil Chloride Derivative $\left(\lambda_{\mathrm{ex}}=397 \mathrm{~nm}\right)$ 


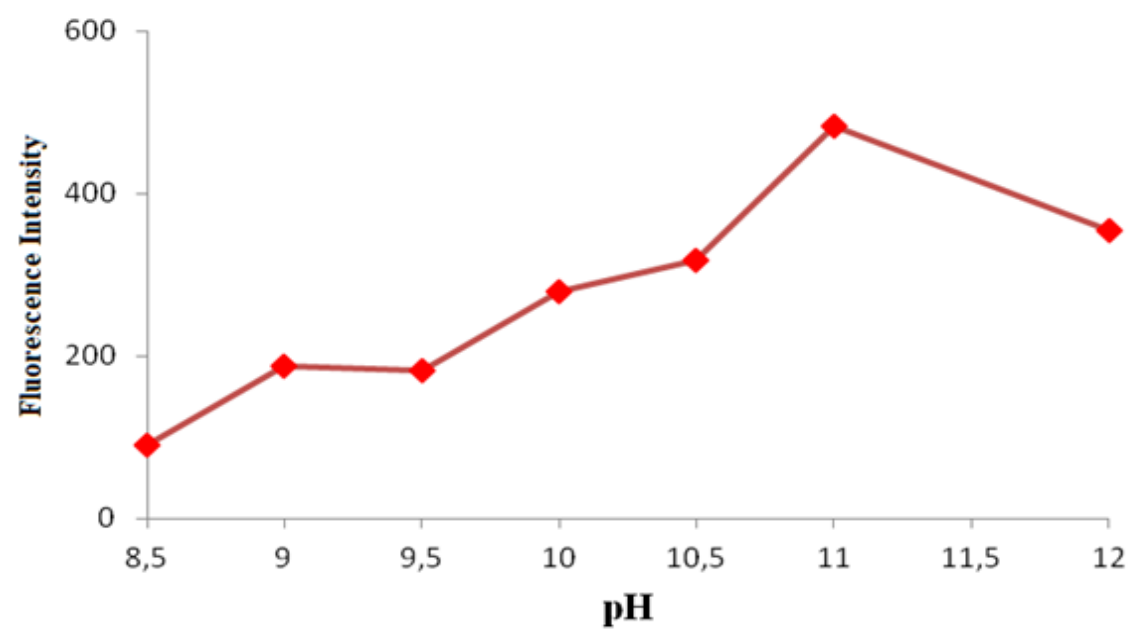

Figure 7. Effect of $\mathrm{pH}$ on the nateglinide-dansyl Derivative

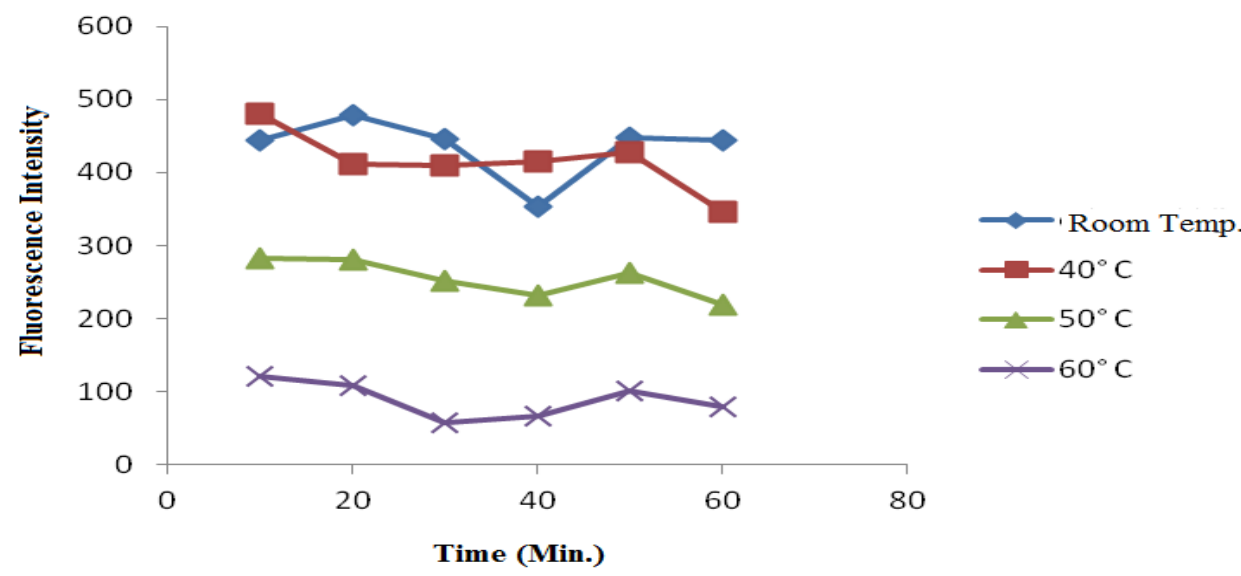

Figure 8. Effect of Time and Temperature on the nateglinide-dansyl Derivative

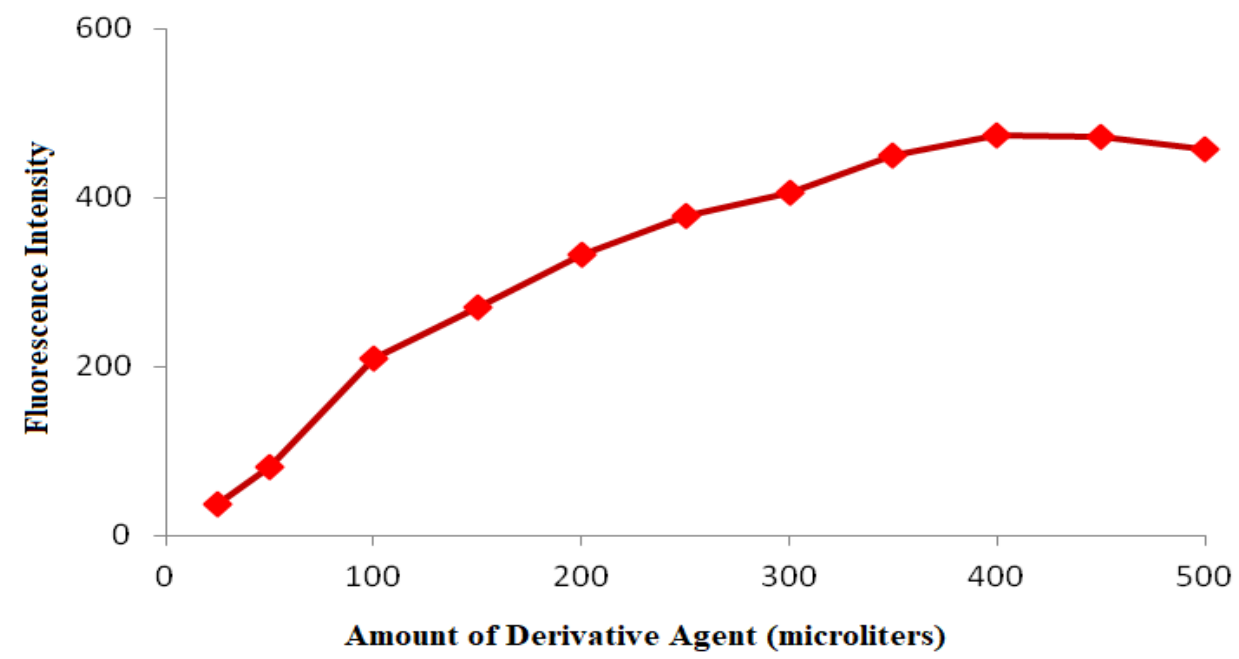

Figure 9. Effect of Dansil Chloride amount on the nateglinide-dansyl Derivative 


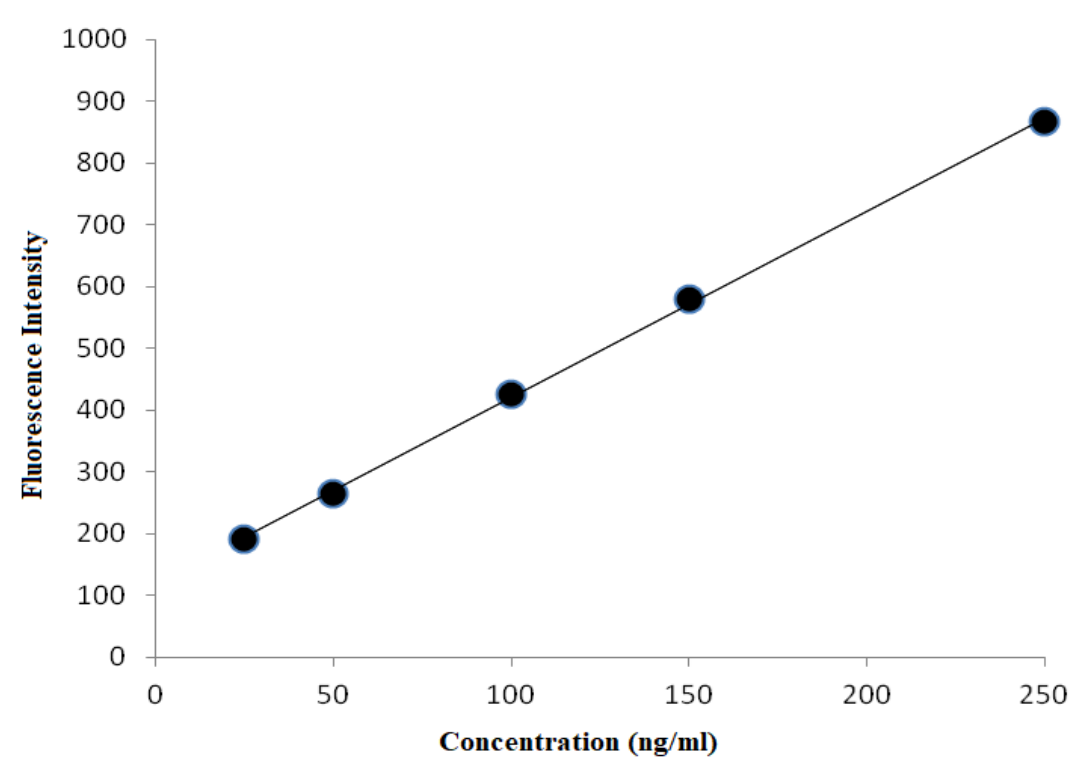

Figure 10. Calibration Curve of Nateglinide $(25-250 \mathrm{ng} / \mathrm{mL})$

Table 4. Effect of Dansil Chloride amount on the nateglinide-dansyl Derivative

\begin{tabular}{|c|c|c|c|c|c|c|c|c|c|c|c|c|}
\hline $\begin{array}{c}\text { Dansil } \\
\text { Chloride }(\mu L)\end{array}$ & 25 & 50 & 100 & 150 & 200 & 250 & 300 & 350 & 400 & 450 & 500 & 550 \\
\hline $\begin{array}{l}\text { Fluorescence } \\
\text { Intensity }\end{array}$ & 36 & 81 & 210 & 270 & 333 & 379 & 406 & 450 & 474 & 472 & 457 & 411 \\
\hline
\end{tabular}

Table 5. Linearity and range - The fluorescence intensity values and the statistical data of the calibration curves prepared in the aqueous solution at the concentration range of $25-250 \mathrm{ng} / \mathrm{mL}$

\begin{tabular}{|c|c|c|c|c|c|c|c|c|c|}
\hline No & $\begin{array}{c}\mathrm{C} \\
\left(\text { ng.mL } \mathbf{L}^{-1}\right)\end{array}$ & $\mathbf{F}_{1}$ & $\mathbf{F}_{2}$ & $\mathbf{F}_{3}$ & $\mathbf{F}_{4}$ & $\mathbf{F}_{5}$ & $\mathbf{F}_{\text {Average }}$ & SD & $\%$ RSD \\
\hline 1 & 25 & 190 & 191 & 191 & 200 & 185 & 191.4 & 5.41 & 2.83 \\
\hline 2 & 50 & 257 & 257 & 257 & 280 & 275 & 265.2 & 11.37 & 4.29 \\
\hline 3 & 100 & 419 & 419 & 419 & 450 & 425 & 426.4 & 13.45 & 3.15 \\
\hline 4 & 150 & 570 & 570 & 570 & 600 & 590 & 580.0 & 14.14 & 2.44 \\
\hline 5 & 250 & 846 & 846 & 846 & 900 & 895 & 866.6 & 28.26 & 3.26 \\
\hline
\end{tabular}

Table 6. Parameters of regression analysis of calibration curves

\begin{tabular}{ccccccc}
\hline & $\mathbf{1}$ & $\mathbf{2}$ & $\mathbf{3}$ & $\mathbf{4}$ & $\mathbf{5}$ & Average \\
\hline $\mathbf{a}$ & 2.9397 & 2.9369 & 2.9369 & 3.1109 & 3.143 & 3.0135 \\
$\mathbf{b}$ & 118.34 & 118.86 & 118.86 & 128.24 & 112.56 & 119.37 \\
$\mathbf{r}$ & 0.9995 & 0.9995 & 0.9995 & 0.9996 & 0.9998 & 0.9996 \\
\hline
\end{tabular}


Table 7. LOD and LOQ values prepared according to the values of parameters of regression

\begin{tabular}{ll}
\hline Parametreler & Değerler \\
\hline Equation of line & $\mathrm{F}=3.0135 \mathrm{C}+119.37$ \\
Slope \pm SD & $3.0135 \pm 0.10$ \\
Intercept \pm SD & $119.37 \pm 4.63$ \\
LOD ng/mL & 6.17 \\
LOQ ng/mL & 18.68 \\
$\mathrm{r}$ & 0.9996 \\
\hline
\end{tabular}

Nateglinide was analyzed at three different concentrations $(25,100$ and $250 \mathrm{ng} / \mathrm{mL})$ within the same day and between days to determine the precision of the developed method. Relative standard deviations for the same day and inter-day analyzes were between $0.11-1.33 \%$ and $0.06-0.85 \%$, respectively (Table 8 and Table 9). We investigated the robustness of the method by making minor changes in parameters such as excitation, emission duration, wavelength response time, and the amount of marker. The RSD values found are 0.027$0.026 \%, 0.022-0.041 \%$ and $0.024-0.029 \%$, respectively. It was observed that the values found were too small to be considered. Results showed that there was no significant change in Assay results. The method is robust in view of changes to Excitation Wave Length, Emission Wave Length, Reaction Time, Dansyl Chloride Amount. (Table 10)

When the stability of the derivative in dichloromethane was examined it was found to be stable at +4 [deg.] C. for 48 hours in the dark. (Table 11)

Table 8: Repeatability of Intraday Analyzes

\begin{tabular}{lccc}
\hline & \multicolumn{3}{c}{$\begin{array}{c}\text { Concentration } \\
(\mathbf{n g} / \mathbf{m L})\end{array}$} \\
& $\mathbf{2 5}$ & $\mathbf{1 0 0}$ & $\mathbf{2 5 0}$ \\
\hline Calculated & 24.39 & 99.72 & 248.27 \\
Concentration & 24.58 & 99.5 & 248.5 \\
(ng/mL) & 24.28 & 99.46 & 248.86 \\
& 23.96 & 99.43 & 249.27 \\
Average & 24.58 & 99.43 & 249.13 \\
Standard Deviation & 24.91 & 99.48 & 249.05 \\
\% RSD & 24.45 & 99.50 & 248.85 \\
\hline
\end{tabular}

Table 9: Repeatability of Interday Analyzes

\begin{tabular}{lccc}
\hline & \multicolumn{3}{c}{$\begin{array}{c}\text { Concentration } \\
(\mathbf{n g} / \mathbf{m L})\end{array}$} \\
& $\mathbf{2 5}$ & $\mathbf{1 0 0}$ & $\mathbf{2 5 0}$ \\
\hline Calculated & 24.62 & 99.67 & 249.48 \\
Concentration & 24.66 & 99.49 & 249.48 \\
(ng/mL) & 24.58 & 99.52 & 249.47 \\
& 24.37 & 99.56 & 250.24 \\
Average & 24.85 & 99.59 & 250.13 \\
Standard Deviation & 24.97 & 99.47 & 250.05 \\
\% RSD & 24.67 & 99.55 & 249.81 \\
\hline
\end{tabular}


Table 10. Robustness

\begin{tabular}{|c|c|c|c|c|c|c|c|c|}
\hline & $\begin{array}{c}\text { Excitation } \\
\text { Wave } \\
\text { Length } \\
\lambda_{\text {eks }}=398 \\
\end{array}$ & $\begin{array}{c}\text { Excitation } \\
\text { Wave } \\
\text { Length } \\
\lambda_{\text {eks }}=396 \\
\end{array}$ & $\begin{array}{c}\text { Emission } \\
\text { Wave } \\
\text { Length } \\
\lambda_{\mathrm{ems}}=518\end{array}$ & $\begin{array}{c}\text { Emission } \\
\text { Wave } \\
\text { Length } \\
\lambda_{\text {ems }}=516 \\
\end{array}$ & $\begin{array}{c}\text { Reaction } \\
\text { Time } \\
\text { (10-1min) }\end{array}$ & $\begin{array}{l}\text { Reaction } \\
\text { Time } \\
(10+1 \mathrm{~min})\end{array}$ & $\begin{array}{c}\text { Dansyl } \\
\text { Chloride } \\
\text { Amount } \\
(400-5 \mu \mathrm{l})\end{array}$ & $\begin{array}{c}\text { Dansyl } \\
\text { Chloride } \\
\text { Amount } \\
(400+5 \mu \mathrm{l})\end{array}$ \\
\hline & 100.03 & 100.09 & 100.06 & 100.89 & 100.00 & 100.10 & 100.01 & 100.02 \\
\hline Calculated & 100.01 & 100.06 & 100.02 & 100.75 & 100.03 & 100.00 & 100.02 & 100.09 \\
\hline \multirow[t]{4}{*}{ Concentration } & 100.00 & 100.04 & 100.30 & 100.66 & 100.01 & 100.08 & 100.06 & 100.08 \\
\hline & 100.05 & 100.02 & 100.04 & 100.02 & 99.99 & 100.07 & 100.07 & 100.10 \\
\hline & 100.07 & 100.07 & 100.45 & 100.30 & 100.05 & 100.06 & 100.02 & 100.06 \\
\hline & 100.01 & 100.08 & 100.28 & 100.10 & 100.01 & 100.12 & 100.03 & 100.09 \\
\hline Average & 100.03 & 100.06 & 100.19 & 100.45 & 100.02 & 100.07 & 100.04 & 100.07 \\
\hline Standard Deviation & 0.027 & 0.026 & 0.177 & 0.363 & 0.022 & 0.041 & 0.024 & 0.029 \\
\hline RSD & 0.027 & 0.026 & 0.176 & 0.361 & 0.022 & 0.041 & 0.024 & 0.029 \\
\hline
\end{tabular}

Table 11. Solution Stability

\begin{tabular}{|c|c|c|c|c|c|}
\hline & \multicolumn{5}{|c|}{ Fluorescence Intensity } \\
\hline & Başlangıç & $\begin{array}{c}6 \text { hours } \\
\text { later }\end{array}$ & $\begin{array}{c}24 \text { hours } \\
\text { later }\end{array}$ & $\begin{array}{c}48 \text { hours } \\
\text { later }\end{array}$ & $\begin{array}{c}72 \text { hours } \\
\text { later }\end{array}$ \\
\hline $\begin{array}{c}\text { Room Temperature } \\
\text { Darkness }\end{array}$ & 423 & 417 & 400 & 364 & 321 \\
\hline $\begin{array}{c}\text { Room Temperature Day } \\
\text { Light }\end{array}$ & 423 & 410 & 393 & 253 & 117 \\
\hline $\begin{array}{l}\text { At }(+) 4^{\circ} \mathrm{C} \\
\text { Darkness }\end{array}$ & 423 & 422 & 420 & 420 & 418 \\
\hline
\end{tabular}

The developed method was applied in the analysis of tablets containing nateglinide. The recovery was $101.20 \%$ and the RSD was $0.43 \%$. In tablet analysis analyzed by pharmacopoeia, recovery was found to be $101.24 \%$ and RSD to be $0.64 \%$. Statistical evaluation of the obtained results was done by calculating the standard deviation, relative standard deviation and confidence limits at the $95 \%$ probability level over 6 trials. It was observed that all the data obtained according to these results meet the requirements of "ICH Q2 (R1)". (Table 12)

Table 12. Analysis of Tablets Containing $120 \mathrm{mg}$ nateglinide and Evaluation of the Results Statistically

\begin{tabular}{|c|c|c|c|c|}
\hline \multirow[b]{2}{*}{ Sample } & \multicolumn{2}{|c|}{ Pharmacopeia Method } & \multicolumn{2}{|c|}{ Developed Method } \\
\hline & mg/Tablet & $\begin{array}{c}\text { Recovery } \\
(\%)\end{array}$ & mg/Tablet & $\begin{array}{c}\text { Recovery } \\
(\%)\end{array}$ \\
\hline 1 & 121.01 & 100.84 & 121.23 & 101.03 \\
\hline 2 & 120.96 & 100.80 & 122.19 & 101.82 \\
\hline 3 & 122.54 & 102.12 & 121.46 & 101.21 \\
\hline 4 & 121.03 & 100.86 & 121.80 & 101.50 \\
\hline 5 & 122.45 & 102.04 & 120.68 & 100.57 \\
\hline 6 & 120.95 & 100.79 & 121.27 & 101.06 \\
\hline $\mathbf{x}$ & 121.49 & 101.24 & 121.44 & 101.20 \\
\hline SD & 0.78 & & 0.52 & \\
\hline$\%$ RSD & 0.64 & & 0.43 & \\
\hline Confidence Interval & 0.82 & & 0.54 & \\
\hline $\mathrm{T}_{\text {Calculated }}=0.13$ & & $\mathrm{t}_{\text {table }}=2.23$ & & \\
\hline $\mathrm{F}_{\text {Calculated }}=2.25$ & & $\mathrm{~F}_{\text {table }}=5.05$ & & \\
\hline $\mathrm{n}_{1}=\mathrm{n}_{2}=6$ & $P=0.05$ & & & \\
\hline
\end{tabular}


In conclusion, this study is economical because the method reported for nateglinide determination in tablets is highly reproducible, simple, sensitive, and very low in quantities. A relative advantage of the method is that the derivative can remain durable for 48 hours in dichloromethane because the relative standard deviations are as small as $1 \%$. The derivatization and extraction processes do not take much time. For this reason, it is thought that biological liquids can be a reliable method for nateglinide analysis and bioavailability studies, as is easily suggested for routine pharmaceutical analyzes.

\section{References}

Abd El-Ghaffar, M.E., El-Wasseef, D.R., El-Sherbiny, D.T. (2011) Spectrofluorimetric Determination of Two beta-Agonist Drugs in Bulk and Pharmaceutical Dosage Forms via Derivatization with Dansyl Chloride. Journal of Analytical Chemistry 66: 476-481

Aksamija A., Mathe C., Vieillescazes C. (2012). Liquid chromatography of triterpenic resins after derivatization with dansyl chloride. Journal of Liquid Chromatography\&Related Technologies 35: $1222-1237$

Higashi, Y., Fujii, Y., (2004). Sensitive determination of the binding of antidepressants to synthetic melanin by liquid chromatography after pre-column derivatization with dansyl chloride. Journal of Liquid Chromatography\&Related Technologies 27: 1903-1914

Higashi Y., Sakata M., Nakamura S. (2008). Simultaneous determination of N-dealkylated metabolites of four butyrophenone-type agents by HPLC with fluorescence detection after pre-column derivatization with dansyl chloride. Journal of Liquid Chromatography\& Related Technologies 31: 2762-2770

ICH Guideline, Q2(R1) Validation of Analytical Procedure: Text and Methodology,

Romero L., Keunchkarian S., Reta M. (2006). Extraction of biogenic amines and their dansyl derivatives with reverse microemulsions of bis [2-ethylhexyl] sulphosuccinate (AOT) prior to high-performance liquid chromatographic determination. Analytica Chimica Acta 565: 136-144

USP Pharma pharmacopoeia XXXIV Edition

Wang Y., Kang Xue-J., Ge Wei-H. (2007). Simple, rapid, and accurate RP-HPLC method for determination of cystine in human urine after derivatization with dansyl chloride. Chromatographia 65: 527-532 